\title{
PERILAKU SUPPORTER SEPAKBOLA PSIM YOGYAKARTA
}

\section{PSIM'S SUPPORTER BEHAVIOUR}

\author{
Vita Fradiantika, Sukadiyanto \\ PPs UNY, Universitas Negeri Yogyakarta \\ fradiantika@gmail.com,sukadiyanto_fik@yahoo.com
}

\begin{abstract}
Abstrak
Penelitian ini bertujuan untuk mengetahui perilaku supporter sepakbola PSIM Yogyakarta. Penelitian ini menggunakan metode kualitatif dengan pendekatan studi kasus. Informan dalam penelitian ini menggunakan tiga orang pengurus Brajamusti, tiga orang pengurus The Maident, dan untuk triangulasi menggunakan subjek Presiden Brajamusti, Ketua Umum The Maident, dan dua anggota kepolisian. Teknik pengumpulan data dalam penelitian ini menggunakan wawancara mendalam dengan pedoman wawancara dan dokumentasi. Hasil penelitian menunjukkan bahwa kedua kelompok supporter Brajamusti dan The Maident berperilaku fanatik dalam memberikan dukungan terhadap PSIM, sehingga sering menimbulkan perkelahian antarsupporter. Faktor yang menjadi penyebab pecahnya Brajamusti adalah faktor politik yang dilakukan oleh pihak tertentu untuk kepentingan politiknya. Dampak positif yang dihasilkan oleh kedua kelompok supporter berupa dukungan finansial hasil pembelian tiket setiap menonton pertandingan PSIM. Sedangkan dampak negatifnya adalah adanya persaingan yang tidak sehat antara Brajamusti dan The Maident sehingga dukungan kepada PSIM menjadi tersamarkan.
\end{abstract}

Kata kunci: perilaku, supporter, sepakbola

\begin{abstract}
This study aims to investigate the behavior of PSIM's (Perserikatan Sepakbola Indonesia Mataram) supporters. This study used qualitative methods with case study approach. Informants used in this study consist of three members of Brajamusti board and three members of the Maident board. For the triangulation, in this study the Brajamusti President, Chairman of The Maident, and two police officers were interviewed. The results showed that Brajamusti and The Maident are behave fanatic in providing support to PSIM, so that often cause fights between supporters. Factor that cause the broken of Brajamusti is political that made by certain parties for political interests. The positive impact of these two groups of supporters are their contribution for buying tickets in every time they watch PSIM, so it can be a financial support. While the negative impact of the two groups of supporters are the unfair competition between them that makes support for PSIM become obscured.
\end{abstract}

Keywords: behavior, football, supporters 


\section{Pendahuluan}

Sepakbola adalah olahraga yang paling digemari oleh seluruh lapisan masyarakat. Tidak mengenal usia, jenis kelamin, serta tingkat sosial kehidupan di dalamnya, sepakbola tetap menjadi olahraga pilihan setiap orang. Pada umumnya masyarakat menyukai olahraga ini dikarenakan sangat populer di mata dunia. Masa depan persepakbolaan di manapun tempatnya belum lengkap apabila tidak menyebut sebuah kelompok yang mempunyai julukan pemain ke-12, atau yang biasa disebut supporter. Menurut Silva (Fernando R., 2008, p.4) pendukung klub sepak bola adalah bagian dari identitas sosial penggemar dari segi mana pengalaman tentang fenomena sepakbola yang dialami oleh para supporter.

Upaya-upaya yang dilakukan oleh para supporter pun beraneka ragam. Dalam mendukung tim kesayangan saat bertanding, para supporter pasti mengenakan atribut-atribut sesuai dengan corak yang dipakai oleh pemainnya. Aksi-aksi dukungan di dalam stadion pun bermacam-macam, mulai dari memainkan alat musik, menyanyikan lagu kebangsaan tim yang dibela, serta menyuarakan yel-yel yang bersifat membangun. Fenomena tersebut akan terlihat pada setiap pertandingan sepakbola di manapun tempatnya.

Supporter adalah bagian penting dalam dunia sepakbola, karena fungsi utama supporter adalah sebagai penyemangat tim sepakbola dalam sebuah pertandingan (Wicaksono, 2011, p.9). Peranan supporter di Indonesia pun tidak kalah pentingnya dari ke-11 pemain yang berlaga di lapangan. Para supporter dengan berbagai atributnya turut serta membela daerah serta memberikan semangat-semangat bermain kepada tim kesayangannya. Mulai dengan nyanyian, gerakan-gerakan yel, serta atribut lain seperti kaos yang mirip dengan yang dipakai oleh tim kesayangan, membuat para supporter dengan lantang melancarkan aksi-aksi dukungan.

Peranan para supporter selain sebagai pendukung kesebelasan, juga banyak memberikan keuntungan bagi klub sepakbola itu sendiri. Tiket masuk stadion yang dibeli oleh para supporter dan juga penonton sangat menguntungkan dan dimaksudkan sebagai devisa klub sepakbola tersebut, sehingga tidak menutup kenyataan bahwa supporter adalah sumber devisa bagi sebuah klub sepakbola selain dari pihak sponsor.
Sepakbola merupakan permainan yang identik dengan laki-laki. Para pemain yang berjumlah 11 orang turun ke lapangan beradu fisik serta taktik guna membobol gawang lawan tidaklah lengkap tanpa kehadiran pemain ke-12. Aksi-aksi dukungan yang dilakukan oleh para supporter bernuansa positif terhadap mental para pemain sepakbola yang sedang bertanding. Semangat mendukung para supporter sangat tinggi terhadap tim yang didukungnya. Dapat dilihat bahwa apapun hasil akhir pertandingan, para supporter tidak akan meninggalkan tim yang didukungnya.

Para supporter tersebut datang dari masing-masing daerah tempat tim sepakbola tersebut berasal. Para supporter dengan sukacita berombongan mendukung tim kesayangan bermain. Tidak peduli waktu panas maupun hujan mengguyur stadion, para supporter dengan lantang menyuarakan yel-yel serta nyanyian khas ala supporter. Dengan demikian hal ini menimbulkan kesan bahwa para supporter adalah kunci dari kelangsungan pertandingan. Apabila terlihat kejanggalan dalam pertandingan, pastilah para supporter yang akan menyuarakannya dengan nyanyian-nyanyian. Tidak jarang pula nyanyian serta yel-yel yang disuarakan oleh para supporter berakibat buruk terhadap jalannya pertandingan. Terkadang hal itu bermula dari saling mengejek antarsupporter, sehingga memicu kemarahan supporter lain dan berakibat rusuh.

Pertikaian, kericuhan, serta bentrokan yang kerap melekat pada setiap laga yang sedang berlangsung, berakibat negatif terhadap cara pandang para penggemar sepakbola ditinjau dari kacamata olahraga. Tidak jarang dari setiap pertandingan yang sedang berlangsung baik itu dari tim tandang maupun tim kandang apabila terdapat beberapa orang dari salah satu supporter berlaku sebagai pemicu timbulnya kerusuhan, pastilah berlanjut dengan aksi rusuh antarsupporter. Kerusuhan yang dilakukan oleh para supporter dinilai sangat merugikan masyarakat. Dikarenakan, setiap terjadi bentrok antarsupporter pasti terdapat kerusakan-kerusakan dan sebagian besar adalah fasilitas umum. Dengan demikian dapat dipastikan bahwa peranan buruk para supporter sepakbola dilihat dari segi apapun adalah sangat merugikan.

Fenomena supporter sepakbola telah memasuki era baru dalam hal mendukung kesebelasan. Peranan para supporter yang semula dapat memacu semangat tim yang didukung sekarang bergeser ke arah yang berbeda. Kadafi 
(2011, pp.10-11) menyatakan bahwa konflik antarsupporter di Indonesia dipicu oleh beberapa faktor dari semua elemen persepakbolaan, tidak hanya dari supporter melainkan juga dari tim sepakbola serta lembaga dan pemerintah yang mengurusi persepakbolaan tersebut.

Relevansi atas pengertian tersebut dapat dilihat di Daerah Istimewa Yogyakarta. Kota Yogyakarta memiliki satu klub sepakbola yang berdiri pada 5 September 1929, yaitu PSIM (Perserikatan Sepakbola Indonesia Mataram). PSIM mempunyai kelompok supporter yang bernama Brajamusti. Namun demikian, dikarenakan terdapat permasalahan di dalam tubuh Brajamusti, maka kelompok supporter tersebut terpecah menjadi dua, sehingga kelompok supporter pendukung PSIM menjadi dua yaitu Brajamusti dan The Maident (Mataram Independent). Peristiwa yang memakan korban juga pernah terjadi di Yogyakarta. Terdapat satu orang supporter The Maident yang sedang berada di area Pakuncen Yogyakarta tiba-tiba dikeroyok dan ditusuk oleh beberapa orang tidak dikenal, berdasarkan (http://rw04-pakuncen.blogspot.com/2012/03/akhiri-konflik-brajamusti-maident).

Tindak anarkis supporter tersebut dipicu karena adanya perpecahan di dalam tubuh Brajamusti yang pecah menjadi Brajamusti dan The Maident. Perpecahan tersebut sangat disayangkan oleh semua elemen yang terdapat di dalam persepakbolaan khususnya di Kota Yogyakarta. Pihak manajemen PSIM juga sangat menyayangkan akan hal tersebut. Namun demikian, dari para petinggi kedua kelompok supporter telah menyepakati akan pemisahan tersebut, sehingga kedua pimpinan masing-masing kelompok telah sepakat untuk berdiri sendirisendiri. Hanya saja pada kelompok arus bawah yang belum dapat menerima adanya perpecahan tersebut, sehingga tindak kekerasan yang melibatkan para supporter kedua kelomok supporter tersebut kerap terjadi.

Perpecahan yang terjadi di dalam kelompok supporter PSIM sangat merugikan terutama bagi PSIM. Telah terjadi kerusuhan yang diakibatkan dari perpecahan tersebut. Puncak peristiwa pemisahan kelompok supporter tersebut terjadi pada pertandingan antara PSIM melawan Persiku pada 12 Maret 2012 yang menewaskan M. Nurul Huda di Jalan Cokroaminoto, Yogyakarta, berdasarkan (http://www.bolaindo.com/2012/03/22/cegah-gesekan-panpelberencana-bubarkan-suporter-psim/). Idealnya, para supporter sepakbola adalah mendukung, namun kenyataannya justru saling berselisih. Oleh karena itu, peneliti akan mengangkat tema dalam penelitian ini di mana peran para supporter sepakbola tidak sesuai dengan harapan.

Permasalahan dalam penelitian ini adalah adanya perilaku negatif dari para supporter PSIM yang memicu terjadinya kerusuhan dan adanya perpecahan dalam tubuh Brajamusti yang merupakan kelompok supporter pendukung PSIM. Penelitian ini bertujuan untuk mengetahui perilaku para supporter PSIM dan untuk mengetahui penyebab terpecahnya kelompok supporter Brajamusti. Penelitian ini bermanfaat sebagai informasi bagi masyarakat tentang perilaku supporter PSIM dan sebagai kajian dan saran tentang perpecahan kelompok supporter Brajamusti.

\section{Metode}

Jenis Penelitian

Penelitian ini merupakan penelitian kualitatif dengan pendekatan studi kasus. Menurut Sukmadinata (2005, p.94) penelitian kualitatif ditujukan untuk memahami fenomenafenomena sosial dari sudut atau perspektif partisipan. Penggunaan metode studi kasus dalam penelitian ini dikarenakan untuk menghimpun dan menganalisis suatu kasus. Menurut Sukmadinata (2005, p.78) studi kasus diarahkan pada mengkaji kondisi, kegiatan, perkembangan, serta faktor-faktor penting yang terkait dan menunjang kondisi dan perkembangan suatu kasus. Partisipan dapat berupa orang-orang yang diwawancara, diobservasi, maupun diminta untuk memberikan data, pendapat, pemikiran, juga persepsinya terhadap masalah yang sedang diteliti.

Bogdan dan Taylor (Meleong, 2007, p.4) mendefinisikan metode kualitatif sebagai prosedur yang menghasilkan data deskriptif berupa kata-kata tertulis atau lisan dari orangorang dan perilaku yang dapat diamati. Sedangkan menurut Denzin dan Lincoln (Meleong, 2007, p.5) penelitian kualitatif adalah penelitian yang menggunakan latar alamiah, dengan maksud menafsirkan fenomena yang terjadi dan dilakukan dengan jalan melibatkan berbagai metode yang ada.

Penelitian kualitatif dirancang untuk mengungkapkan berbagai khalayak target perilaku dan persepsi dengan mengacu pada topik tertentu. Konsep dasarnya adalah menggunakan studi yang mendalam dari kelompok kecil orang untuk mendukung pembangunan perta- 
nyaan penelitian. Penelitian kualitatif ini berusaha mengungkap gejala secara menyeluruh, dan sesuai dengan konteks melalui pengumpulan data dengan memanfaatkan diri peneliti sebagai instrumen kunci.

Alasan peneliti melakukan penelitian jenis kualitatif adalah untuk mengetahui berbagai perilaku supporter klub sepakbola PSIM Yogyakarta secara jelas dan untuk mengetahui penyebab terpecahnya kelompok supporter Brajamusti menjadi dua yaitu Brajamusti dan The Maident (Mataram Independent). Dengan demikian, dengan menggunakan penelitian jenis kualitatif, akan didapat faktor terkecil berbagai perilaku para supporter penyebab terpecahnya kelompok supporter Brajamusti tersebut.

\section{Waktu dan Tempat Penelitian}

Waktu penelitian dilakukan dalam tiga tahap, yaitu tahap persiapan, tahap pengumpulan data, dan tahap pengecekan data. Tahap persiapan yaitu tahap pengamatan awal untuk memantapkan permasalahan penelitian dan menentukan subjek penelitian. Tahap persiapan ini dilakukan mulai bulan Januari sampai Februari 2013. Selanjutnya tahap pengumpulan data, yaitu dilakukan dengan wawancara, mengamati, dan mencari berbagai informasi yang berhubungan dengan fokus dan permasalahan penelitian. Ketiga tahap pengecekan data yaitu tahap mengadakan check and recheck data guna memperkuat hasil penelitian. Tahap ini dilakukan dengan cara mendiskusikan kembali hasil penelitian. Penelitian ini dimulai pada bulan Februari hingga April 2013 bertempat di base camp Brajamusti dan base camp The Maident dan dilakukan juga di Stadion Mandala Krida Yogyakarta.

\section{Subjek Penelitian}

Dalam penelitian kualitatif tidak dikenal populasi dan sampel penelitian, sehingga yang dimaksud sampel dalam penelitian kualitatif adalah informan. Informan di sini merujuk pada individu atau kelompok yang dijadikan unit yang diteliti. Informan dalam penelitian ini adalah tiga pengurus Brajamusti, tiga pengurus The Maident, dan untuk keperluan triangulasi subjek yang diwawancarai adalah ketua masing-masing kelompok supporter dan dua anggota dari kepolisian, yaitu yang pertama dari Polsek Umbulharjo dan yang kedua dari Polresta Yogyakarta.

\section{Instrumen Penelitian}

Penelitian ini menggunakan instrumen pedoman wawancara, catatan lapangan, rekaman suara, dan pengambilan gambar dengan kamera. Kisi-kisi umum berupa daftar pertanyaan disusun berdasarkan pada dua faktor yang mendasari perilaku supporter PSIM yaitu dari faktor internal maupun eksternal. Indikator-indikator yang berpengaruh terhadap kedua faktor tersebut di antaranya faktor latar belakang supporter, status kepribadian, motivasi, aspek kognitif, aspek afektif, aspek konatif, dan lingkungan.

\section{Teknik Pengumpulan Data}

Teknik pengumpulan data dalam penelitian ini menggunakan observasi, wawancara, dan dokumentasi.

\section{Observasi}

Observasi dapat dilakukan dengan penglihatan serta pendengaran untuk memperoleh informasi yang diperlukan untuk menjawab masalah penelitian. Hasil observasi dapat berupa aktivitas, kejadian, peristiwa, objek, kondisi tertentu, dan perasaan emosi seseorang. Observasi dilakukan untuk memperoleh gambaran nyata suatu peristiwa untuk menjawab pertanyaan penelitian. Menurut Moleong (2007, p.174) pengamatan adalah berperan penting, dikarenakan apabila peneliti menginginkan keyakinan atas keabsahan data tersebut, maka peneliti akan mengamati sendiri suatu peristiwa yang menjadi objek kajiannya.

\section{Wawancara}

Pada hakikatnya wawancara merupakan kegiatan untuk memperoleh informasi secara mendalam tentang sebuah isu atau tema yang diangkat dalam penelitian. Menurut. Moleong (2007, p.186) wawancara adalah percakapan dengan maksud tertentu. Tujuan wawancara adalah untuk mengetahui objek kajian yang ingin diteliti, untuk keperluan triangulasi, serta untuk memverifikasi objek kajian yang ingin diteliti. Penelitian ini menggunakan pedoman wawancara yang digunakan peneliti dalam mengumpulkan data di lapangan.

\section{Dokumentasi}

Dokumentasi bertujuan untuk mendapatkan data sekunder yang dapat mendukung keakuratan data. Dari data ini dapat diketahui peristiwa di masa lampau hingga saat penelitian dilakukan. 
Teknik Analisis Data

Teknik analisis data adalah teknik pengumpulan data secara sistematis untuk mempermudah peneliti dalam memperoleh kesimpulan. Dalam penelitian kualitatif analisis data dilakukan sejak awal penelitian dan selama proses penelitian dilaksanakan. Data yang diperoleh kemudian dikumpulkan untuk diolah secara sistematis. Dimulai dari wawancara, observasi, mengedit, mengklasifikasi, mereduksi, selanjutnya proses penyajian data serta penyimpulan data. Teknik analisis data dalam penelitian ini menggunakan teknik analisis data dari Miles dan Huberman.

\section{Hasil Penelitian dan Pembahasan}

Berdasarkan penelitian tentang perilaku supporter sepakbola khususnya supporter PSIM Yogyakarta, peneliti telah menemukan apa saja yang menjadi penyebab perilaku para supporter baik positif maupun negatifnya. Beberapa hal yang mendasari perilaku para supporter dalam mendukung PSIM adalah karena kecintaannya terhadap PSIM. Para supporter tersebut mengaku menyukai PSIM dari dalam hati dan berupaya untuk selalu memberikan yang terbaik bagi PSIM.

Upaya-upaya yang dilakukan oleh para supporter yaitu dengan menciptakan kreativitas seni yang tertuang dalam lagu-lagu, yel-yel, dan gerakan koreo yang selalu ditampilkan pada saat mendukung PSIM. Kedua organisasi wadah supporter baik Brajamusti maupun The Maident masing-masing mempunyai ciri khas yang terlihat dari warna kaos ataupun atribut yang digunakan pada saat mendukung PSIM. Brajamusti mempunyai kaos berwarna biru sedangkan The Maident mempunyai kaos berwarna hitam. Berikut gambar yang menunjukkan suasana di dalam Stadion Mandala Krida pada saat pertandingan PSIM.

Filosofi tersebut dari Brajamusti diambil dari warna kebanggaan PSIM yaitu biru, sedangkan The Maident menggunakan warna hitam dikarenakan merupakan lambang kebebasan dalam mendukung PSIM dan menjadi organisasi wadah supporter yang independent. Kesadaran para supporter dalam mendukung PSIM berangkat dari rasa loyalitas terhadap PSIM. Para supporter mengaku akan mendukung PSIM sampai titik darah penghabisan.

Masing-masing organisasi wadah supporter tersebut mempunyai anggota yang berjumlah hingga ribuan orang. Pengkondisian dan sarana berkomunikasi dilakukan melalui media sosial seperti facebook, twitter, BBM (Blackberry Messenger), serta melalui telepon dan SMS (Short Message Service). Sebagai sarana mempererat silaturahmi dan hubungan persaudaraan, masing-masing organisasi mempunyai cara sendiri, yaitu dengan berkumpul mengadakan acara hingga touring mengunjungi anggota supporter yang berada di luar daerah.

Masalah pendanaan masing-masing organisasi wadah supporter mempunyai cara yang sama, yaitu dengan mengumpulkan dana serkiler seikhlasnya dari para anggota supporter yang akan menyelenggarakan perjalanan atau tour ke luar daerah. Pengkoordinasian para anggota tersebut dilakukan setiap setelah musim pertandingan, sehingga efektif, dan pada setiap akan menjelang musim pertandingan, para anggota supporter tersebut berkumpul untuk merencanakan kegiatan berikutnya yang akan dilakukan.

Para pemimpin dari masing-masing kelompok supporter selalu berusaha memberikan pengertian kepada para anggotanya agar mendukung secara kreatif. Namun demikian, tidak semua supporter yang berada di bawah payung kedua organisasi wadah supporter tersebut mengindahkannya. Tidak jarang kerusuhan terjadi, akan tetapi masalah tersebut dapat dengan cepat diselesaikan oleh kedua belah pihak. Kedua pemimpin dari masing-masing organisasi wadah supporter tersebut saling berupaya membangun organisasi masing-masing dengan selalu mengedepankan kreativitas dalam mendukung. Namun demikian, fakta yang terlihat di lapangan adalah justeru terdapat persaingan yang tidak sehat di antara keduanya.

Berdasarkan pengamatan di lapangan, peneliti mendapatkan data bahwa saat mendukung PSIM, tidak jarang kedua wadah supporter tersebut justeru terlibat saling ejek. Keadaan tersebut tentunya sangat disayangkan oleh pihak PSIM. Namun demikian, kedua wadah supporter tersebut belum menemukan solusi untuk menyelesaikan perselisihan. Pihak PSIM hanya dapat berharap setiap mendukung PSIM, kedua wadah supporter tersebut dapat mengkondisikan para anggotanya agar tidak terjadi hal-hal yang nantinya akan merugikan PSIM.

Berdasarkan pengamatan di lapangan, saat wawancara, dan pengambilan dokumentasi diperoleh hasil penelitian bahwa hal yang mendasari perilaku para supporter dalam mendukung PSIM adalah karena fanatik terhadap PSIM. Para supporter tersebut mengaku me- 
nyukai PSIM dari dalam hati dan berupaya untuk selalu memberikan yang terbaik bagi PSIM. Upaya-upaya yang dilakukan oleh para supporter yaitu dengan menciptakan kreativitas seni yang tertuang dalam lagu-lagu, yel-yel, dan gerakan koreo yang selalu ditampilkan pada saat mendukung PSIM.

Berdasarkan pengamatan di lapangan, peneliti mendapatkan data bahwa saat mendukung PSIM, tidak jarang kedua wadah supporter tersebut justru terlibat saling ejek. Keadaan tersebut tentunya sangat disayangkan oleh pihak PSIM. Namun demikian, kedua wadah supporter tersebut belum menemukan solusi untuk menyelesaikan perselisihan. Pihak PSIM hanya dapat berharap setiap mendukung PSIM, kedua wadah supporter tersebut dapat mengkondisikan para anggotanya agar tidak terjadi hal-hal yang nantinya akan merugikan PSIM.

Kondisi seperti yang dialami PSIM merupakan hal yang langka di Indonesia. Permasalahan serius yang terjadi di dalam sebuah tim yang mempunyai dua kelompok pendukung tentunya sangat disayangkan oleh tim yang bersangkutan juga para penggemar sepakbola. Pada dasarnya kelompok supporter adalah nyawa bagi tim yang dibelanya. Namun demikian, seperti yang terjadi pada PSIM, keadaan seperti itu tentunya akan sangat berpengaruh terhadap prestasi PSIM. Terdapat dua kelompok supporter yang berselisih paham tentu akan merugikan PSIM dari segi apapun, sehingga solusi untuk menyatukan kedua wadah supporter tersebut sangat diperlukan untuk kebaikan PSIM.

Terpecahnya kelompok supporter PSIM menjadi dua yaitu Brajamusti dan The Maident dilihat dari aspek latar belakang mempunyai tujuan yang sama yaitu untuk memberikan dukungan kepada PSIM. Para supporter Brajamusti dan The Maident yang diwawancarai oleh peneliti memberikan kesimpulan bahwa pada dasarnya tujuan The Maident berdiri adalah untuk memberikan dukungan terhadap PSIM dengan cara yang berbeda. Para supporter yang tergabung dalam Brajamusti memberikan pendapat bahwa The Maident berdiri karena para pengurusnya tidak puas dengan hasil musta (musyawarah tahunan) yang dilaksanakan secara rutin setiap tahunnya.

Berdasarkan hasil musta (musyawarah tahunan) tersebut, terpilihlah E.S.P sebagai Presiden Brajamusti yang baru. Sedangkan rivalnya yang kini menjadi pengurus The Maident, pada waktu itu merasa tidak puas akan hasil musta (musyawarah tahunan) tersebut, sehingga menimbulkan kecemburuan sosial dan akhirnya berujung pada pemisahan diri dan membentuk kelompok supporter baru. Apabila ditanyakan tentang tujuan, maka para supporter baik Brajamusti maupun The Maident sama-sama bertujuan untuk mendukung PSIM sampai mati.

Peristiwa tersebut akan mengarahkan kedua kelompok supporter tersebut ke dalam konflik berkepanjangan. Konflik yang terjadi akibat pecahnya Brajamusti menimbulkan banyak spekulasi dari masyarakat seputar isu politik yang menjadi penyebab utamanya. Permasalahan tersebut tidak akan menemukan titik terang apabila tidak ditemukan solusi integratif untuk mendamaikan kedua kelompok yang saling berselisih. Dengan kata lain, konflik akan terus berlanjut apabila masing-masing pihak berusaha untuk mencapai tujuannya meskipun harus dengan membebankan kerugiannya pada pihak lain.

Berdasarkan pengamatan di lapangan pada saat menyaksikan pertandingan PSIM melawan PERSIS Solo, peneliti mendapat hasil yaitu pada saat salah satu anak gawang tidak mau mengambilkan bola yang keluar yang akan diambil oleh pemain PERSIS Solo. Anak gawang tersebut dengan sengaja tidak mau mengambilkan bola dengan alasan PSIM dan PERSIS Solo merupakan derby yang telah turuntemurun dari nenek moyang terdahulu. Kemudian setelah diminta oleh kapten dari PSIM, barulah anak gawang tersebut bersedia mengambilkan bola yang keluar tersebut.

Selain itu pada saat salah seorang pemain PERSIS Solo akan melakukan tendangan pojok, para supporter Brajamusti dengan kompak melempari pemain tersebut dengan botol, sehingga pertandingan menjadi ricuh sejenak. Setelah diredam oleh wasit, para supporter pun menghentikan pelemparan. Namun demikan, berdasarkan hasil pengamatan di atas, memberikan informasi bahwa tindak anarkis para supporter Brajamusti memberikan dampak negatif bagi PSIM. Bagaimanapun juga nama baik PSIM akan tercoreng dan otomatis berpengaruh terhadap prestasi PSIM di kancah yang lebih besar.

Menurut pendapat peneliti, hal tersebut merupakan titik minus dari para supporter yang bertindak anarkis yang justeru merugikan PSIM. Selain itu, dapat dikatakan bahwa Brajamusti dan The Maident dalam kiprahnya mendukung PSIM tidak maksimal lagi dan justeru berorientasi terhadap organisasinya masingmasing. Keadaan demikian menjadikan du- 
kungan terhadap PSIM menjadi berkurang dan jauh dari harapan para supporter yang secara fanatik mendukung PSIM untuk mencapai laga di ISL.

Perilaku kedua kelompok supporter tersebut pertama dilihat dari latar belakang mengikuti Brajamusti maupun The Maident adalah untuk dapat menyalurkan ide-ide dalam memberikan dukungan kepada PSIM. Para supporter yang mempunyai keinginan secara pribadi menyatakan bahwa dukungan kepada PSIM sangat besar dan akan selalu mendukung PSIM apapun yang terjadi. Kedua, hal tersebut dapat menentukan status kepribadian para supporter yang tergabung dalam Brajamusti maupun The Maident.

Status kepribadian yang dimaksud adalah pengertian dan kebanggan menjadi supporter Brajamusti maupun The Maident. Para supporter menyatakan bahwa dengan mengikuti kelompok supporter, para supporter tersebut dapat mengekspresikan bentuk-bentuk kecintaan kepada PSIM. Dilihat dari rasa kebanggaan yang mendalam, menimbulkan rasa fanatik sehingga para supporter akan melakukan segala cara demi mendukung PSIM. Ketiga, motivasi para supporter dalam mendukung PSIM harus disertai dengan loyalitas yang tinggi. Perwujudan dari rasa loyalitas kepada PSIM ditunjukkan dengan selalu mengawal di manapun saat PSIM bertanding.

Selain dengan selalu mengawal saat PSIM bertanding, para supporter yang tergabung dalam Brajamusti maupun The Maident sama-sama mempunyai solidaritas antaranggota yang ditunjukkan dengan selalu bersama-sama saat dalam perjalanan maupun di dalam stadion. Kebersamaan yang diusung oleh para supporter menimbulkan motivasi dan kecintaan yang besar terhadap PSIM menimbulkan keinginan yang besar pula bagi para supporter untuk mengikuti wadah supporter baik Brajamusti maupun The Maident.

Keempat, perilaku para supporter yang didasari oleh aspek lingkungan dapat dilihat dari banyaknya laskar yang terbentuk dari berbagai daerah di seluruh wilayah Daerah Istimewa Yogyakarta. Jaringan kelompok supporter yang terdapat di beberapa kota di pulau Jawa menggambarkan bahwa lingkungan juga turut berpengaruh terhadap kemajuan kedua kelompok supporter tersebut. Dengan kata lain, orientasi untuk mendukung PSIM menjadi berkurang karena kelompok supporter tersebut menjadi lebih mengutamakan kepentingan organisasinya dan mengembangkannya hingga dikenal oleh seluruh supporter yang ada di Indonesia.

Selanjutnya dilihat dari aspek kognitif menggambarkan bahwa para supporter dari Brajamusti dan The Maident sama-sama mempunyai pemikiran bahwa tidak ada persyaratan untuk menjadi supporter. Seseorang bebas memberikan dukungan kepada PSIM, walaupun tidak bergabung dengan wadah supporter, tapi sudah dapat disebut sebagai supporter. Peraturan di dalam kelompok supporter pun tidak mengikat para anggotanya. Peraturan yang terdapat di dalam Brajamusti merupakan peraturan yang diatur secara normatif dan tidak membebankan anggotanya. Sedangkan di dalam The Maident, peraturannya terdapat di ADART kepengurusan The Maident.

Menurut peneliti, pernyataan di atas termasuk ke dalam teori sosiologi massa yang mengatakan bahwa nilai dan norma sosial di setiap kelompok bersifat relatif. Menurut Setiadi dan Kolip (2011, p.191) yang dimaksud relatif adalah nilai dan norma yang berlaku di dalam kelompok satu mungkin atau bisa saja tidak berlaku di kelompok sosial lainnya. Berdasarkan pernyataan di atas, peneliti dapat menyimpulkan bahwa para pengurus Brajamusti yang memutuskan untuk berpisah dan mendirikan wadah supporter baru dikarenakan tidak cocoknya prinsip dan ide-ide yang dimiliki keduanya dalam memberikan dukungan kepada PSIM.

Selanjutnya dilihat dari aspek afektif para supporter Brajamusti dan The Maident dalam mendukung PSIM menunjukkan bahwa komando yang diberikan oleh para pemimpin kedua wadah supporter tersebut selalu diikuti oleh anggotanya. Persiapan-persiapan yang dilakukan pada saat sebelum menonton pertandingan PSIM selalu diatur dengan rapi. Para supporter yang tergabung dalam laskar-laskar datang ke stadion dengan berombongan dan berkonvoi mengendarai sepeda motor. Perilaku tersebut ditujukan agar eksistensi kelompok supporter baik Brajamusti maupun The Maident mendapat pengakuan dari masyarakat.

Pernyataan di atas didukung oleh teori pengendalian sosial yang menyatakan bahwa dengan melakukan pengendalian sosial, seseorang ataupun sebuah kelompok dapat mendorong seseorang atau anggota kelompok agar berperilaku selaras dengan kehendak seseorang atau kelompok tertentu, Cohen (Setiadi dan Kolip, 2011, p.252). Berdasarkan teori di atas, dapat disimpulkan bahwa Brajamusti dan The 
Maident secara langsung maupun tidak langsung dan secara sadar maupun tidak sadar sudah memberikan pengaruh kepada para anggotanya untuk berperilaku sebagai supporter yang berada di bawah kendali kelompoknya.

Selanjutnya aspek konatif yang mendasari perilaku para supporter Brajamusti maupun The Maident dalam memberikan dukungan kepada PSIM dinilai belum maksimal. Pernyataan di atas dibuktikan dari tidak sportifnya para supporter dalam memberikan dukungan. Hal tersebut dilihat dari masih adanya perkelahian yang dilakukan oleh para supporter baik itu antara Brajamusti dengan The Maident maupun Brajamusti dan The Maident dengan supporter lawan. Peneliti menemukan bukti pada saat menyaksikan pertandingan PSIM melawan PERSIS Solo.

Dalam pertandingan tersebut terlihat Brajamusti dan The Maident sama-sama menyanyikan lagu dan teriakan yang sama untuk mengejek para pemain PERSIS Solo. Keadaan demikian merupakan dampak dari derby yang sudah turun-temurun dari generasi terdahulu. Setelah dikonfirmasikan dengan Presiden Brajamusti, hal tersebut merupakan hal yang wajar karena para supporter Brajamusti dan PSIM juga mendapatkan perlakukan yang sama pada saat bertandang ke Solo, sehingga aroma permusuhan antara Brajamusti dan Pasoepati tidak akan menemukan titik temu yang akan mendamaikan keduanya.

Pada saat dikonfirmasikan dengan Ketua Umum The Maident terkait dengan permusuhan tersebut, Ketua Umum The Maident menyatakan bahwa pihaknya telah berupaya untuk berdamai dengan Pasoepati karena dinilai The Maident sudah bukan bagian dari Brajamusti lagi. Namun demikian, dari upaya yang dilakukan oleh pihak The Maident tersebut belum dapat diterima oleh arus bawah Pasoepati, sehingga sampai sekarang permusuhan masih berlangsung. Peristiwa di atas membuktikan bahwa perilaku para supporter PSIM baik itu Brajamusti maupun The Maident belum sepenuhnya membuktikan loyalitasnya kepada PSIM.

Menurut peneliti, loyalitas kepada PSIM seharusnya ditunjukkan dengan cara yang tidak anarkis, karena cara tersebut justeru akan mencoreng nama PSIM sendiri. Masing-masing pemimpin baik itu dari Brajamusti maupun The Maident seharusnya memberikan pengendalian sosial yang baik kepada anggotanya, sehingga tidak berbuat anarkis. Dengan melakukan pengendalian sosial yang baik dirasa akan mem- berikan dampak yang baik pula bagi PSIM. Karena sejauh yang peneliti dapatkan pada saat wawancara dengan beberapa supporter baik Brajamusti maupun The Maident, pemimpin kedua kelompok supporter tersebut terkesan lepas dalam menyikapi anggotanya yang mempunyai paham anarkis.

Menurut Presiden Brajamusti maupun Ketua Umum The Maident, para supporter tersebut memiliki paham tersendiri untuk menunjukkan kecintaannya terhadap PSIM. Namun demikian, apabila hal tersebut dilakukan dengan cara anarkis justeru akan berakibat tidak baik bagi PSIM, karena apabila terdapat permasalahan terkait dengan supporter, maka yang akan mendapat sanksi adalah PSIM. Oleh karena itu, sangat disayangkan apabila pemberian dukungan kepada PSIM dilakukan dengan cara yang salah, karena pemimpin kelompok supporter yang tidak memberikan pengendalian sosial yang tepat bagi para anggotanya.

Berdasarkan hasil penelitian di atas dapat ditarik kesimpulan yang pertama penyebab pecahnya Brajamusti menjadi Brajamusti dan The Maident dikarenakan ketidakpuasan pihak yang satu terkait dengan hasil Musta (musyawarah tahunan) untuk memilih Presiden Brajamusti. Kegagalan aspirasi tersebut menimbulkan perubahan psikologis yang berakibat adanya agresi. Agresi yang dimaksud adalah sikap tidak terima akan keputusan yang didapat, sehingga berdampak pada pemisahan diri dari Brajamusti. Pernyataan tersebut semakin kompleks ditambah dengan dukungan kelompok politik yang berada di belakang kedua pihak yang berseteru.

Dikarenakan konflik yang terjadi di dalam tubuh Brajamusti yang sudah tidak berada pada payung yang sama, membuat pihak yang ingin memisahkan diri tersebut semakin kuat untuk berdiri sendiri. Teori yang menyebutkan bahwa seseorang yang mempunyai kekuasaan potensial dan aktual dapat mengantarnya pada tujuan yang ingin dicapai. Pembuktian dari teori tersebut dapat dilihat dari pemilihan Walikota Yogyakarta yang menggunakan masa untuk mendukungnya. Karena seseorang yang menjadi Walikota Yogyakarta otomatis akan menjadi salah satu pengurus PSIM dan menjadi Dewan Pembina supporter yang mendukung PSIM. Oleh karena itu, jelas terlihat bahwa olahraga telah digunakan sebagai kendaraan politik bagi sejumlah pihak yang ingin memperoleh kekuasaan. 
Pecahnya Brajamusti menjadi Brajamusti dan The Maident tentu akan berdampak negatif bagi PSIM. Pernyataan tersebut dibuktikan dari perselisihan dan persaingan yang kerap ditampilkan oleh kedua wadah supporter tersebut pada saat mendukung PSIM. Upaya yang dilakukan para supporter dari kedua wadah untuk mendukung PSIM menjadi tidak bermakna karena masing-masing wadah justeru mengutamakan kepentingan untuk mengembangkan organisasinya. Menurut peneliti, sebuah tim sepakbola yang mempunyai dua wadah supporter yang mendukungnya tidak akan mendapatkan dukungan yang maksimal, karena kedua wadah supporter tersebut hanya akan bersaing untuk mendapatkan pengakuan dari PSIM.

Berdasarkan teori yang menyatakan bahwa konflik yang terjadi di dalam organisasi yang berdampak mempengaruhi sejumlah individu dan organisasi serta proses dan hasil keputusan. Dalam kelompok supporter Brajamusti dan The Maident, konflik yang terdapat di dalamnya merupakan duri tajam yang sukar untuk dicabut, karena permasalahan yang dihadapi oleh kedua belah pihak telah melibatkan massa yang besar, sehingga apabila belum ditemukan solusi yang tepat, maka konflik antara keduanya akan terus berlanjut hingga ke generasi berikutnya.

Berdasarkan uraian di atas mengenai hasil penelitian tentang perilaku supporter sepakbola PSIM Yogyakarta, maka diperoleh kesimpulan bahwa proses mendukung kesebelasan yang dilakukan oleh kedua wadah supporter baik Brajamusti maupun The Maident sangat disayangkan oleh berbagai pihak terutama dari manajemen PSIM. Keputusan tersebut dirasa akan berdampak negatif bagi prestasi PSIM. Karena perilaku yang ditampilkan pada saat mendukung justeru bernada saling mengejek antara Brajamusti dan The Maident.

Relevansi atas permasalahan di atas dapat dilihat pula pada saat pemain sepakbola legenda dunia yaitu Diego Armando Maradona datang ke Indonesia pada 29 Juni 2013. Kegiatan Maradona ke Indonesia dijadwalkan berlangsung selama empat hari, yang setiap harinya akan diisi dengan kunjungan Maradona ke beberapa kota di Indonesia. Namun demikian, selain untuk kunjungan bertemakan olahraga sepakbola, banyak yang menerka-nerka apabila Maradona diundang ke Indonesia untuk keperluan kampanye politik yang berada di Kota Makassar Propinsi Sulawesi Selatan. Mendengar kabar tersebut, sontak Maradona terlihat marah dan tidak habis pikir bahwa kedatangannya yang diharapkan sebagai teladan bagi generasi muda persepakbolaan di Indonesia, tetapi justru dimanfaatkan oleh pihak yang berkepentingan politik. Oleh karena itulah relevansi atas permasalahan di Kota Yogyakarta yang membenarkan teori bahwa olahraga merupakan kendaraan politik.

Selama 35 tahun klub sepakbola dari Daerah Istimewa Yogyakarta belum ada yang pernah lolos dalam PON (Pekan Olahraga Nasional). Kondisi tersebut merupakan kondisi yang sangat memprihatinkan dari masa depan olahraga sepakbola khususnya di Daerah Istimewa Yogyakarta. Mengingat hal tersebut merupakan sebuah dampak dari konflik berkepanjangan tentang persepakbolaan di Daerah Istimewa Yogyakarta, maka sebaiknya konflik tersebut segera dituntaskan.

Terkait dengan isu politik yang erat dengan kelompok supporter di Daerah Istimewa Yogyakarta, sebaiknya jangan terlalu dibesar-besarkan, karena justeru akan menambah masalah lebih panjang lagi. Apabila mencintai klub sepakbola di Daerah Istimewa Yogyakarta, maka persoalan tentang satu klub dengan dua kelompok supporter harus segera dituntaskan.

\section{Simpulan dan Saran}

\section{Simpulan}

Perilaku yang ditunjukkan oleh Brajamusti dan The Maident dalam mendukung PSIM adalah perilaku fanatik yang tidak jarang menimbulkan kerusuhan. Kerusuhan yang dimaksud adalah perkelahian antarsupporter hingga mengakibatkan jatuhnya korban. Munculnya perilaku fanatik tersebut dikarenakan para supporter sangat mencintai PSIM, sehingga rela melakukan apa saja demi membela PSIM.

Faktor yang menjadi penyebab terpecahnya kelompok supporter Brajamusti adalah faktor politik. Karena kegagalan dalam musyawarah tahunan yang diselenggarakan oleh Brajamusti mengakibatkan pecahnya kelompok supporter tersebut. Terpecahnya Brajamusti menjadi dua dimanfaatkan oleh pihak yang berkepentingan politik untuk dijadikan massa pendukung, sehingga terbentuklah The Maident sebagai kelompok supporter baru yang secara resmi mendukung PSIM.

Dampak positif yang dihasilkan oleh kedua kelompok supporter tersebut dapat dilihat dari sumbangan oleh para supporter dengan 
cara selalu membeli tiket pada setiap menonton pertandingan PSIM, sehingga hal tersebut dapat menjadi dukungan finansial kepada PSIM selain dari semangat yang selalu diberikan pada saat mendukung PSIM bertanding.

Dampak negatif yang dihasilkan oleh Brajamusti dan The Maident adalah karena kedua kelompok supporter tersebut saling berselisih, maka dukungan semangat yang diberikan kepada PSIM menjadi kurang maksimal. Kedua kelompok supporter tersebut justeru saling bersaing untuk mendapatkan posisi sebagai kelompok supporter yang resmi mendukung PSIM.

Berdasarkan paparan di atas, dapat dikatakan bahwa pecahnya kelompok supporter PSIM menjadi Brajamusti dan The Maident sangat merugikan PSIM. Karena kedua kelompok tersebut saling bersaing untuk mengembangkan organisasinya, sehingga dukungan terhadap PSIM menjadi tersamarkan.

Saran

Brajamusti dan The Maident merupakan kelompok supporter yang mendukung PSIM, oleh karena itu dalam memberikan dukungan diharapkan dapat memberikan bentuk dukungan yang besar terutama untuk meningkatkan prestasi PSIM. Dengan cara meminimalisir perselisihan di antara keduanya.

Apabila mencintai persepakbolaan di Daerah Istimewa Yogyakarta, maka konflik yang menyangkut satu klub sepakbola dengan dua kelompok supporter harus segera dituntaskan. Diharapkan Brajamusti dan The Maident dapat bersatu lagi demi PSIM. Karena dilihat dari sejarah pencarian nama Brajamusti yang sangat menyentuh, maka sangat disayangkan apabila harus berakhir dengan perpecahan.

Kondisi persepakbolaan di Daerah Istimewa Yogyakarta bukan berada di tangan para elit politik, melainkan di tangan para penggemar sepakbola itu sendiri. Oleh karena itu, diharapkan dengan dukungan yang besar terhadap jalannya persepakbolaan yang bersih dan disiplin, akan melahirkan prestasi yang membanggakan bagi Daerah Istimewa Yogyakarta.

\section{Daftar Pustaka}

Bola Indo. (2012). Cegah gesekan, panpel berencana bubarkan supporter PSIM. Diakses tanggal 20 Juli 2012 dari http://www.bolaindo.com/2012/03/22/c egah-gesekan-panpel-berencanabubarkan-suporter-psim/\#.

Fernando, Wachelke Joao. (2008). Brazilian fans' social representations on soccer. Representaciones sociales de los hinchas brasileños sobre fútbol [versi elektronik]. International Journal of Sport Science Volume IV, 1-9

Kadafi, Muamar. (2011). Konflik antar-supporter sepakbola meruntuhkan persatuan dan kesatuan bangsa Indonesia. Artikel: STIMIK AMIKOM Yogyakarta.

Moleong, Lexy J. (2007). Metode penelitian kualitatif. Bandung: PT. Remaja Rosdakarya.

Setiadi, Elly M. dan Kolip, Usman. (2011). Pengantar sosiologi pemahaman fakta dan gejala permasalahan sosial: teori, aplikasi, dan pemecahannya. Jakarta: Kencana.

Sukmadinata, Nana Syaodih. (2005). Metode penelitian pendidikan. Bandung: PT. Remaja Rosdakarya.

RW 04 Pakuncen. (2012). Akhiri konflik Brajamusti-Maident, "supporter PSIM korban penusukan meninggal. Diakses tanggal 20 Juli 2012 dari http://rw04pakuncen.blogspot.com.

Wicaksono, Agam Rizki. (2011). Tidak adanya rasa persatuan antarsupporter sepakbola. Artikel: STIMIK AMIKOM Yogyakarta. 